University of Chicago Law School

Chicago Unbound

Journal Articles

Faculty Scholarship

2009

\title{
Effects of Liberalization on Litigation: Notes Toward a Theory in the Context of Japan
}

Tom Ginsburg

Glenn Hoetker

Follow this and additional works at: https://chicagounbound.uchicago.edu/journal_articles

Part of the Law Commons

\section{Recommended Citation}

Tom Ginsburg \& Glenn Hoetker, "Effects of Liberalization on Litigation: Notes Toward a Theory in the Context of Japan," 8 Washington University Global Studies Law Review 2 (2009).

This Article is brought to you for free and open access by the Faculty Scholarship at Chicago Unbound. It has been accepted for inclusion in Journal Articles by an authorized administrator of Chicago Unbound. For more information, please contact unbound@law.uchicago.edu. 


\title{
THE EFFECTS OF LIBERALIZATION ON LITIGATION: NOTES TOWARD A THEORY IN THE CONTEXT OF JAPAN
}

\author{
TOM GINSBURG* \\ GLENN HOETKER**
}

\begin{abstract}
This Essay examines the under-studied relationship between liberalization and litigation. Liberalization should lead to expanded civil litigation for four reasons: (1) new market entrants are less subject to informal sanctions and may have a greater propensity to go to court; (2) privatization transfers resources away from the state, expanding the number of transactions subject to civil law regimes; (3) liberalization reduces the government's ability to resolve disputes outside the courts; and (4) liberalization leads to economic development, which is generally litigation-enhancing. We test these propositions using a unique dataset of prefecture-level civil litigation data in Japan during the 1990s. Using panel data, we find a small but significant effect of foreign firms on litigation.
\end{abstract}

\section{INTRODUCTION}

In his classic 1978 article, The Myth of the Reluctant Litigant, John Haley used institutional analysis to demolish the dominant culturalist view of Japanese litigation behavior. ${ }^{1}$ Haley's foil, Takeyoshi Kawashima, had applied the dominant modernization theses of his time to understand Japanese law and society. ${ }^{2}$ Haley, on the other hand, was prescient in shifting the analysis to institutional factors. Within two decades, the various new institutionalisms had come to dominate the social sciences,

* Professor of Law, University of Chicago, and Director, Center on Law and Globalization, American Bar Foundation. Thanks to Travis Kennedy and Akira Shimizu for research assistance.

** Associate Professor of Business Administration and Director, Center for International Business Education and Research (CIBER), University of Illinois, Urbana-Champaign.

1. John Haley, The Myth of the Reluctant Litigant, 4 J. JAPANESE STUD. 359 (1978).

2. Takeyoshi Kawashima, Dispute Resolution in Contemporary Japan, in LAW IN JAPAN: THE LEGAL ORDER IN A CHANGIng SOCIETY 41 (Arthur Taylor von Mehren ed., 1963). 
and with them sociolegal studies as well. Thanks to Haley, Japanese law became a bellwether of this broader trend. ${ }^{3}$

This Essay revisits the litigation debate from a quite distinct angle, one that might be called "Taking Kawashima Seriously." For many decades, scholars have puzzled over the relationship between legal institutions and economic development. By and large, this literature has treated law as an independent variable that constrains or facilitates growth. ${ }^{5}$ Far less attention has been paid among economists and lawyers to the effect of development on litigation, which was Kawashima's implicit framework. It has been observed for some time that law and economic development likely have a reciprocal relationship. ${ }^{6}$ Not only does good law facilitate development, but development creates new demands on the legal system and arguably increases the scope of transactions governed by law in the economy. Yet there has been very little exploration of this direction of causality in the recent literature.

In an earlier paper, we identified a complex relationship between development and litigation rates, using prefecture-level data from Japan. On the one hand, litigation is countercyclical. Holding other factors constant, growth seems to dampen demand for litigation. As the economic pie expands, forgiving behavior has lower marginal costs and so there is less willingness to go to court. ${ }^{8}$ On the other hand, higher per capita income seems to increase demand for litigation. More wealth implies more transactions per capita, so that even if the rate of "bad" transactions stays constant, there is more litigation in the economy. We found that the growth effect was larger than the wealth effect, but that both were statistically significant determinants of increased litigation in Japan in the

3. The litigation debate in Japan was also an early topic for economic analysis of comparative law. See J. Mark Ramseyer \& Minoru Nakazato, The Rational Litigant: Settlement Amounts and Verdict Rates in Japan, 18 J. LEGAL STUD. 263 (1989); J. Mark Ramseyer, Reluctant Litigant Revisited: Rationality and Disputes in Japan, 14 J. JAPANESE STUD. 111 (1988).

4. See Setsuo Miyazawa, Taking Kawashima Seriously: A Review of Japanese Research on Japanese Legal Consciousness and Disputing Behavior, 21 LAW \& SOC'Y REV. 219 (1987); Tom Ginsburg \& Takao Tanase, Japanese Litigiousness and "Taking Kawashima Seriously," Proceedings from the 2005 Sho Sato Conference in Honor of Takao Tanase (Feb. 12-13, 2005), available at http:/www.law.berkeley.edu/centers/ilr/pub_sho_sato_2005.

5. See Tom Ginsburg \& Thomas Ulen, What We Know-and Don't Know-About Law and Economic Development (on file with authors); Rafael La Porta, Florencio Lopez-de-Silanes, Andrei Shleifer \& Robert W. Vishny, Law and Finance, 106 J. POL. ECON. 1113 (1998).

6. See Lawrence Friedman, On Legal Development, 24 RUTGERS L. REV. 11 (1969).

7. See Tom Ginsburg \& Glenn Hoetker, The Unreluctant Litigant?: An Empirical Analysis of Japan's Turn to Litigation, 35 J. LEGAL STUD. 31 (2006).

8. Id. 
1990s. ${ }^{9}$ We did not, however, identify the mechanisms by which the economy affects litigation rates. ${ }^{10}$

In this Essay, we suggest that liberalization-defined as the elimination of barriers to entry of newer players in the market-is a key determinant of resort to legal dispute resolution mechanisms. By allowing in new players, liberalization expands the pool of economic actors and disrupts cooperative equilibria that may have previously emerged and become stabilized. New players may be less embedded in reputational networks that can contribute to informal forms of contract enforcement. Furthermore, liberalization creates a more competitive environment, pushing firms to adopt more vigorous strategies to seek economic advantage. These factors may make both new and old firms less "forgiving" of opportunism by contract partners.

The Essay is organized as follows. Part I explores the theoretical relationship between liberalization and litigation. Part II describes liberalization in Japan in the 1990s, and explains why foreign firms may have acted as agents of transmission of new norms. Part III concludes with a discussion of the implications of the analysis for Haley's thesis and for theories of law and development.

\section{LIBERALIZATION AND LITIGATION}

The 1990s saw significant shifts toward liberal political economy in many countries of the world. Pushed by the so-called "Washington Consensus," policy reform in developing countries revolved around a series of measures designed to enhance the role of markets. ${ }^{11}$ Sometimes known as neoliberalism, these policies were an example of a more general process of liberalization, comparable to other such movements in history. Liberalization means many things to different people, including greater emphasis on fiscal discipline, privatization, and rollback or removal of substantive government regulation. At its core, however, liberalization involves the relaxation and removal of barriers to marketplace entry so as to facilitate enhanced opportunities for trade.

We believe that liberalization might contribute to greater demand for litigation through a number of modalities. First, the elimination of barriers to entry encourages new market participants to conduct economic activity,

9. Id.

10. Id.

11. See John Williamson, What Washington Means by Policy Reform, in LATIN AMERICAN AdJUSTMENT: How MuCH Has HaPPENEd 7 (John Williamson ed., Inst. for Int'l Econ. 1990). 
and these participants may, ceteris paribus, be more likely to litigate when disputes arise. Second, liberalization reduces the direct role of government in the economy, increasing demand for civil dispute resolution. Third, liberalization reduces government's capacity to act as a substitute dispute resolver, shifting disputes toward the courts. Fourth, liberalization can indirectly encourage more litigation through its effect on wealth. This, however, is offset by the growth effect, which dampens litigation. We discuss each of these modalities in turn.

\section{A. New Entrants}

A major goal of liberal economic policies is to allow new entrants into the marketplace. Other things being equal, new entrants may have a greater propensity to sue than established players in particular markets. Sociologists of law have long observed that litigation is less likely in close-knit groups because of the relationship-breaking quality of going to court. ${ }^{12}$ Close-knit groups develop norms through repeated interactions over time. Norms can provide guidance to appropriate behavior, which can reduce the frequency of breach. When breach does occur, repeated interactions allow players to punish opportunism. Punishment can occur directly, when the injured party refuses to transact with the norm-violator, or by third parties who enforce reputational sanctions.

Reputation-based contract enforcement is easier to apply when all participants know each other. As the number of players in a market expands, the use of reputational sanctions becomes more difficult, as such actions depend on second order norms about sanctioning wrongdoing. New players, in particular, are unlikely to benefit from these reputational sanctioning mechanisms, and are also less likely to suffer from them as information on past performance is less available. Hence both new players, and established players who are transacting with new players, may be more likely to go to court when problems occur. New entrants might be more likely to be plaintiffs or defendants than established players.

In some cases, selective liberalization of particular sectors can have a broader effect by allowing the entry of particular agents of litigious behavior. Most obviously, liberalization of legal services markets in recent years has allowed foreign law firms to penetrate previously closed arenas. Lawyers, like any other actors, bring with them new strategies and

12. See Donald Black, The Boundaries of Legal Sociology, 81 YALE L.J. 1086 (1972); ROBERT Ellickson, ORder Without LAW: HOW NEIGHBORS SETTLE DisPuTES (1991); Richard McAdams, The Origin, Development, and Regulation of Norms, 96 MICH. L. REV. 338 (1997). 
technologies to try to advance their interests, and it is quite likely that these strategies would tend more toward formal than informal dispute resolution. ${ }^{13}$ As foreign lawyers adopt more formalistic strategies, local firms may respond in kind, ratcheting up the willingness of parties to go to court.

\section{B. Privatization}

A second reason that liberalization is likely to encourage litigation is that liberalization programs, at least in recent decades, are typically accompanied by privatization-the reduction in direct government provision of goods and services that are not true public goods. Privatization by definition means that more of the economy is in private hands. Even assuming that rates of litigation among market actors are constant, we should see greater overall rates of civil litigation as more transactions are subject to that legal regime, as opposed to administrative court systems that sometimes have jurisdiction over government contracting. $^{14}$

Of course, even when government is directly involved in the provision of goods and services, it might willingly allow itself to be sued, avoiding doctrines of sovereign immunity. Government is likelier to do this when it does not maintain its own monopoly in the relevant sector. For example, a government-owned oil company would find itself paying a higher cost of capital and higher prices for supplies if it did not allow itself to be sued, for contract partners would demand greater returns in exchange for the risk of government non-performance. But when government effectively retains a monopoly, for example in many areas of welfare provision, it may not allow itself to be sued in contract or tort. Altogether, then, we should expect that privatization would encourage litigation.

Note that the transfer of resources to the private sector interacts with the presence of new entrants to enhance incentives to litigate. Privatization by definition expands the scope of transactions subject to civil litigation regimes; it can also lead to the expansion of the number of firms. When government sells assets, it sometimes does so to new entrants into the market. One can characterize liberalization as leading to the entry of new potential plaintiffs into the economy, while privatization involves the

13. George Nnona, Multidisciplinary Practice Through Developing-Country Lenses: The Imperatives of the Nigerian Regulatory Context, 25 BERKELEY J. INT 'L. L. 346 (2007).

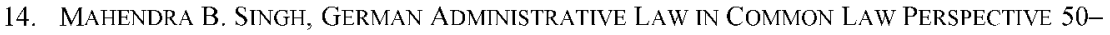
$62(1985)$. 
creation of new potential defendants. Together, the presence of new plaintiffs and new defendants makes the establishment of a reputational equilibrium difficult. Information on past performance may be unavailable; hence players may be more willing to go to court at the first sign of opportunism.

\section{Removal of Government As Substitute Dispute Resolver}

Another reason liberalization expands litigation is that the removal of substantive regulation reduces government's ability to resolve disputes directly. To understand this point, consider that extensive government regulation can dampen or serve as an effective substitute for litigation. When government regulation is extensive, and the government is directly involved in the production of goods and services, firms that do business with the government can expend energy in political rent-seeking rather than bringing cases to court. In addition, when government discretion is high, it can exert collateral leverage over private firms and suppress disputes among the various players in a sector. Substantive deregulation, by reducing discretionary controls over the economy, also reduces government ability to impose costs on firms that it wishes to sanctionand this means that the government is less attractive as a dispute resolver.

Japanese political economy provides an example of the role of regulation in dispute resolution. In the high-growth period, the Japanese government retained control over numerous resources needed by firms, including capital, export credits, and licenses. ${ }^{15}$ The government frequently utilized these tools to direct firms into business decisions that the government felt were desirable, and to eliminate "excess competition" from the system. Indeed, in some cases, the government would punish firms for deviations in one area using collateral tools that affected another business decision. ${ }^{16}$ When private firms in a particular sector would have disputes, the government was in a good position to help resolve them. Toshiyuki Kōno characterizes this function as that of a "motionless mediator," a role in which government sat at the center of regulatory networks and resolved disputes among firms. ${ }^{17}$ This managerial function

15. CHALMERS JOHNSON, MITI AND THE JAPANESE MIRACLE (1982).

16. Michael Young, Judicial Review of Administrative Guidance: Governmentally Encouraged Consensual Dispute Resolution in Japan, 84 ColUM. L. REV. 923, 927-28 (1984); Haley, supra note 1 .

17. Toshiyuki Kōno, Judges and Mediators in Japan: The Administration As Motionless Mediator?, in JAPAN: ECONOMIC SUCCESS AND LEGAL SYSTEM 69 (Harald Baum ed., 1997); see also JOHN OWEN HALEY, AUTHORITY WITHOUT POWER: LAW AND THE JAPANESE PARADOX 139-68 
of government may have been one factor in suppressing litigation during the high-growth period. The government role in dispute suppression was hardly visible, but many knowledgeable observers report its existence. ${ }^{18}$

It is not clear whether the under-capacity of the legal system was a cause or effect of the tight business-government ties, but the two sets of institutions were without a doubt complementary. Because the government handled many disputes and suppressed others, there was relatively little demand for formal resolution of disputes by the courts. However, as the legal system became more powerful in the $1990 \mathrm{~s}$, the bureaucracy lost power. This shift can be seen today in the market for talent, as top graduates of the prestigious University of Tokyo Faculty of Law increasingly turn to legal professions rather than front-line ministries. ${ }^{19}$ We also see a clear shift of disputes from bureaucratic toward legal resolution. For example, in 2005, Sumitomo Trust \& Banking brought a lawsuit to block a proposed merger between UFJ and Mitsubishi Tokyo. ${ }^{20}$ This suit would have been unimaginable in Japan just a decade earlier, because the Ministry of Finance would have resolved it behind closed doors.

Generalizing this point, governments that heavily regulate the economy-particularly those that employ extensive bureaucratic discretion-may play a crucial role in suppressing some disputes from ever emerging and in resolving those that do emerge. This function would generally serve to dampen litigation. As regulatory tools disappear with liberalization, government's dispute-suppressing role may also decline.

\section{The Wealth Effect}

Finally, liberalization can indirectly contribute to more litigation. A staple of the law and development literature was an assumption that modernization would lead to greater reliance on formal institutions. ${ }^{21}$ Most obviously, wealthier societies have more transactions per capita, so that even if tendencies to litigate remain constant, there will be more disputes to resolve. Of course, this must be balanced against the fact that there are

(1991); Bruce Aronson, The Brave New World of Lawyers in Japan 5-16 (working paper, Aug. 16, 2007), available at http:/papers.ssrn.com/sol3/papers.cfm?abstract_id=1008334\#PaperDownload.

18. See, e.g., Kōno, supra note 17.

19. Curtis Milhaupt \& Mark West, Law's Dominion and the Market for Legal Elites in Japan, 34 LAW \& POL'Y INT'L BUS. 451, 469-73 (2003).

20. Curtis Milhaupt, In the Shadow of Delaware? The Rise of Hostile Takeovers in Japan, 105 COLUM. L. REV. 2171 (2005).

21. See Friedman, supra note 6. 
opportunity costs to litigation. Time and money spent in court are more valuable in richer societies, even if the absolute value of the transactions at stake is also higher. We take no view on whether these two effects offset. Still, we believe the findings of our earlier work are likely to be robust. Growth tends to suppress litigation because the opportunity costs are higher, while the marginal cost of "forgiving" behavior is lower. Wealth, on the other hand, encourages litigation because of greater transactional density. Assuming that the effects we observed in our earlier article are robust, liberalization would contribute indirectly to more demand for litigation through a wealth effect, even as short-term growth effects dampened demand.

\section{LIBERALIZATION IN JAPAN}

Japan experienced significant liberalization in the 1990s, and provides an ideal testing ground for some of the conjectures presented here. During the high growth period, Japan was famous for its low rates of litigation. ${ }^{22}$ It also had significant barriers - formal and informal — to foreign entry into many markets.

Traditional accounts of Japanese political economy emphasize the significant role of the government in the economy. ${ }^{23}$ Government regulators, it is usually argued, had a good deal of discretion in regulatory policy, and, importantly for our argument, played a role in suppressing and managing disputes. Firms relied on the government to resolve disputes over the allocation and use of property rights. Some scholars describe how the government provided a substitute for legal forms of dispute resolution, actively channeling disputes away from the courts by setting up alternative fora. ${ }^{24}$ Others emphasize an even less formal role in which firms looked to government to resolve problems arising from intense competition. In this account, government bureaucrats stood at the center of policy networks, a position that allowed them to coordinate across firms and issue areas. ${ }^{25}$

22. See Ginsburg \& Hoetker, supra note 7, at 31; Christian Wollschläger, Historical Trends of Civil Litigation in Japan, Arizona, Sweden, and Germany: Japanese Legal Culture in the Light of Judicial Statistics, in JAPAN: ECONOMTC SUCCESS AND LEGAL SYSTEM 89, 93-94 (Harald Baum ed., 1997).

23. See JOHNSON, supra note 17.

24. Frank Upham, LaW and Soclal Change in Postwar Japan (1987); Takao Tanase, The Management of Disputes: Automobile Accident Compensation in Japan, 24 LAW \& SOC'Y REV. 651, 675-78 (1990).

25. Kōno, supra note 17 , at 69 . This image is somewhat controversial, in large part because of the work of J. Mark Ramseyer and his co-authors. See J. MARK RAMSEYER \& FRANCES MCCALL ROSENBluth, JAPAN'S POLITICAL MARKETPLACE (1993); J. MARK RAMSEYER \& MiNORU 
A central feature of Japanese political economy was so-called convoy capitalism. ${ }^{26}$ The basic idea was that entire economic sectors should move as a convoy, with leaders helping to bring up laggards. Key firms would not be allowed to go out of business, allowing economy-wide promises, including lifetime employment, to be met. In return for their role in helping out weaker firms during downturns, the leading firms received regulatory forbearance. This system, of course, is the consummate relational or insider regulatory scheme, with most communication being informal and taking the role of "administrative guidance" rather than formal legal commands.

One of the results of the economic downturn in the 1990s was a set of significant adjustments in the relationships among economic actors and the government. These were spurred, in part, by pressure from outside, particularly from the Structural Impediments Initiative ("SII") talks with the United States in the late $1980 \mathrm{~s} .^{27}$ Believing that informal trade barriers were largely responsible for low market share among American firms in Japan, the United States government pushed for greater transparency, a freer flow of information, and the adoption of rules such as an administrative procedures act. Japan's mandarins largely resisted these calls. But the economic downturn associated with the bubble economy provided new political impetus for adjustments in governance.

In particular, the brief fall of the Liberal Democratic Party in 1993 led to the passage of the Administrative Procedures Law. ${ }^{28}$ This law encouraged transparency, forcing government officials either to refrain from or formalize practices of "administrative guidance." Many believed that these formal rules regulating government activity would be merely cosmetic and would not lead to significant change. ${ }^{29}$ But apparently they had a significant effect. For example, well-placed observers report that

NAKAZATO, JAPANESE LAW: AN ECONOMIC APPROACH (1999). The thrust of this work has been to show that Japan's bureaucrats were serving the interests of the country's long-governing Liberal Democratic Party and did not exercise overall control over the economy. Instead their discretion was highly constrained. These political links became much clearer as Japan's economy stumbled badly beginning in 1989 . The image of bureaucratic dominance began to give way to a more nuanced view of the bureaucracy as merely one participant in policy networks.

26. See Yoshinori Shimizu, Convoy Regulation, Bank Management, and the Financial Crisis in Japan, in JAPAN's FINANCIAL CRTSIS AND ITS PARALLELS TO U.S. EXPERIENCE 57 (Ryoichi Mikitani \& Adam S. Posen eds., 2000).

27. Warren Murayama, The WTO: Domestic Regulation and the Challenge of Shaping Trade, 37 INT'L L. 677 (2003).

28. Administrative Procedure Act, Law No. 88 of 1993; Tom Ginsburg, Dismantling the "Developmental State"? Administrative Procedure Reform in Japan and Korea, 49 AM. J. COMP. L. 585,586 (2001).

29. See id. 
government officials stopped answering questions as to the legality of proposed activities, which in turn increased demand for private legal advice. $^{30}$

Another reason that firms might have begun to turn away from government was a general decline in the reputation of the bureaucracy. Japan's vaunted bureaucrats, who had been seen as supermen in the 1980s, had in fact presided over an economic bubble of outrageous proportions. Their steps to bring the economy out of recession were largely failures. No doubt this significantly eroded the willingness of private firms to trust government. These ties were further eroded as government began to break the implicit promises that had sustained the business-government networks for so long, particularly the convoy system. In the financial sector, for example, it was widely believed that government had made an implicit promise that firms would not be allowed to fail. ${ }^{31}$ In 1997, however, the prominent securities firm Yamaichi Securities went under. This was followed a few weeks later by the failure of Tokuyō City Bank. ${ }^{32}$

In response, the Japanese government launched the so-called "Big Bang" to encourage rationalization of the banking sector. ${ }^{33}$ In exchange for a bailout program, Japan's banking, insurance, and securities sectors were significantly opened to foreign investment and ownership. The approach was a shift toward more formal and transparent regulation, and away from the "ex ante planning" model of economic policy. ${ }^{34}$ A wave of mergers followed and a vigorous competition ensued.

It was widely reported that foreign banks became much more aggressive about collecting bad loans and debts in the $1990 \mathrm{~s} .{ }^{35}$ Because debt collection is considered a form of civil litigation in Japan, this alone led to increased rates of litigation, and is consistent with our theory linking liberalization to litigation. In addition to the financial sector, non-financial firms invested. Total inward foreign direct investment ("FDI") flows increased from $¥ 678$ billion in 1997 to $¥ 2.1$ trillion by 2001 , tripling the

30. See Aronson, supra note 17.

31. See Jennifer A. Amyx, Japan's Financial Crisis: institutional Rigidity and RELUCTANT CHANGE (2004).

32. Id. at 182

33. See id.

34. JUSTICE System REForm COUNCIL, RECOMMENDATIONS OF THE JUSTTCE SYSTEM REFORM COUNCIL - FOR A JUSTICE SYSTEM TO SUPPORT JAPAN IN THE 21ST CENTURY (2001), available at http://www.kantei.go.jp/foreign/judiciary/2001/0612report.html.

35. See, e.g., Yasuharu Nagashima \& E. Anthony Zaloom, The Rise of the Large Japanese Business Law Firm and lits Prospects for the Future, in LAW IN JAPAN: A TURNING POINT? 136 (Daniel H. Foote ed., 2008). 
stock by $2002 .{ }^{36}$ Presumably, the entry of new players into the market corresponded with significant changes in strategy.

We also expect that the entry of foreign firms led Japanese financial institutions to be more aggressive about debt collection. In short, liberalization seemed to lead to a positive increase in incentives to use formal mechanisms of dispute resolution while undermining the leverage that had underpinned firm reliance on government to resolve disputes.

Beyond entry of new players, Japan undertook some element of privatization during the period in question. Most notable was Prime Minister Junichirō Koizumi's effort to privatize the massive postal savings system so as to facilitate market allocation of capital. ${ }^{37}$ Koizumi sought to transform the very basis of the postwar political economy and to change the way his political party operated.

Finally, liberalization in the legal services sector further bolstered formal methods of dispute resolution. Into the early 1990s, foreign lawyers were subject to strict regulation which limited their practice in Japan and prevented them from hiring or going into partnerships with Japanese lawyers. Partly in response to the SII talks and other forms of U.S. pressure, the law was amended in 1994 to become less restrictive. In 2003, partnerships between foreign and Japanese lawyers were finally allowed. This corresponded with a much more competitive market for legal services, and with the growth of larger corporate law firms. ${ }^{38}$

In short, Japan underwent significant regulatory changes in the 1990s that liberalized the economy. These had an increasingly observable effect, accelerating after 1998, on FDI and the entry of foreign firms. As the legal market also liberalized, we observed a sharp increase in litigation in Japan. ${ }^{39}$ Our analysis here is speculative and suggestive only. Elsewhere, we demonstrate more systematically that litigation is responsive to liberalization. ${ }^{40}$

36. Ministry of Econ., Trade \& Indus., Inward Foreign Direct Investment (FDI) Trends in Japan, http:/www.meti.go.jp/english/policy/index_FDI_into_Japan.html (follow "Inward Foreign Direct Investment (FDI) Trends in Japan" hyperlink).

37. Susan Carpenter, Koizumi's Reform of Special Corporations, 3 J. INT'L BUS. \& L. 67, 69-70 (2004).

38. See Aronson, supra note 17; Nagashima \& Zaloom, supra note 35, at 140-45.

39. Ginsburg \& Hoetker, supra note 7, at 36-37.

40. Tom Ginsburg \& Glenn Hoetker, Liberalization and Litigation: Evidence from Japan (unpublished manuscript, on file with authors). 


\section{LIBERALIZATION AND MODERNIZATION THEORY}

Our analysis is primarily institutional in character, but allows for some connection with cultural theories of litigant behavior. We see outsiders as crucial agents of litigation behavior, prone to use more formal means of resolving disputes because they are less embedded in culturally specific networks. We believe that outsiders do contribute to greater levels of litigation in a society, and that these effects increase over time, presumably because other agents copy the outsider strategy. This provides a hypothesis about cultural change with regard to litigation behavior.

In the 1950s and 1960s, modernization theory saw the emergence of universally applied, general rules of behavior as a particular feature of modernity, and as normatively desirable. Kawashima saw in Japan's relatively low litigation rates in the $1960 \mathrm{~s}$ a residual pre-modern consciousness, implying that legal consciousness would change with time and Japan would move toward higher ("normal") rates of litigation. ${ }^{41}$

Other "height of modernization" theorists noted a decline of litigation as societies modernized. Litigation, noted Lawrence Friedman, sometimes declines with economic growth. ${ }^{42}$ Friedman has argued that litigation decreases because of rising costs. ${ }^{43}$

Our argument is inconsistent with Friedman's conjecture and supports Kawashima's view. Proponents of the view that Japanese culture was antilitigious were essentially describing an institutionally-sustained equilibrium in which incentives to litigate were suppressed. Analysts talked about or rationalized this state of affairs as a cultural aversion, and to the extent that their discourse had impact on downstream agents, sustained the low-equilibrium outcome by suppressing agents' incentives to deviate. Cultural discourse and institutional factors thus reinforced themselves in a recursive process.

As Haley and other critics of cultural theories have long argued, cultures are dynamic and change over time. By facilitating the entry of new agents, liberalization promises (or threatens) to disrupt previously stable equilibria, facilitating a shift to new equilibria. We have described such a process in Japan: a stable institutional equilibrium came under pressure as a result of economic downturn; a new political coalition

41. Kawashima, supra note 2, at 43.

42. Lawrence Friedman, Litigation in Society, 15 ANN. REV. Soc. 17, 24 (1989).

43. Friedman, Legal Rules and the Process of Social Change, 19 StAN. U. L. REV. 786, 801 (1967) (" $[T]$ he tremendous expansion of business could have led to an appetite for litigation far beyond the capacities of the courts, the rising price of going to court has prevented this from happening."). 
adopted liberalizing policies; and agents responded by changing behavior, producing greater levels of litigation than had previously been imaginable. This account supplements the institutional incentives story pioneered by Haley in $1978 .^{44}$

44. Haley, supra note 1. 
HeinOnline -- 8 Wash. U. Global Stud. L. Rev. 3162009 